\title{
HANGTOMPÍTÓ AKUSZTIKAI TERVEZÉSE HIBRID MÓDSZERREL
}

\author{
Barhm Mohamad \\ PhD hallgató, Miskolci Egyetem, Gép-és Terméktervezési Intézet \\ 3515 Miskolc, Miskolc-Egyetemváros, e-mail: pywand@gmail.com \\ Jálics Károly \\ egyetemi docens, Miskolci Egyetem, Gép-és Terméktervezési Intézet \\ 3515 Miskolc, Miskolc-Egyetemváros, e-mail: machijk@uni-miskolc.hu
}

\section{Andrei Zelentsov}

egyetemi docens, Bauman Moscow State Technical University, Piston Engine Department 105005 Moscow, Russia, e-mail: Zelentsov.aa@gmail.com

\begin{abstract}
Absztrakt
A kipufogó- és hangtompitó zaj egy kihivást jelentö probléma a gépjármüiparban. Noha a rendszer fö célja a motorból származó akusztikus impulzusok intenzitásának csökkentése, az ilyen rendszerek által kiváltott ellennyomást a lehetö legkisebbre kell csökkenteni, hogy garantálják a motor maximális teljesitményét. Ez a tanulmány egy hatékony eljárást mutat be egy Formula Student versenyautó (FS) reaktiv hangtompitója átviteli veszteségének optimalizálására analitikai módszerek alkalmazásával. Ennek során létrehoztuk a hangtompitó CAD modelljét, majd ezt az AVL BOOST-ban és más fejlett kereskedelmi forgalomban elérhetö tervezö szoftver (SolidWorks 2017) segitségével egy végeselemes akusztikai (FEA) modellé alakitottuk. A modell segitségével az áramlási tulajdonságokat, a nyomást és a sebességet vizsgáltuk. A modell ellenőrzése után elvégeztük a tervezési paraméterek érzékenységvizsgálatát a hangtompitó hangnyomásszintjének (SPL) optimalizálása érdekében. Javaslatokat tettünk egy egyenletesebb SPL görbe elérésére.
\end{abstract}

Kulcsszavak: Formula Student, hangtompitó, hangnyomásszint, 3D szimuláció

\begin{abstract}
Exhaust and muffler noise are a challenging problem in the industry. While the main purpose of the system is to reduce the intensity of the acoustic pulses originating from the engine exhaust valves, the back pressure induced by these systems must be kept to a minimum to guarantee maximum performance of the engine. This study presents an efficient process to optimize the transmission loss of Formula Student race car (FS) reactive muffler by using analytical methods. CAD file of the muffler was established for developing the FEA model in AVL BOOST and another commercial advanced design software (SolidWorks 2017). The flow properties, pressure and velocity were moitored. After the model was verified, sensitivity studies of design parameters were performed to optimize the sound pressure level (SPL) of the muffler. Recommendations are made for obtaining smoother SPL curves.
\end{abstract}

Keywords: Formula Student, muffler, SPL, 3D simulation

\section{Bevezetés}

A kipufogó hangtompító kialakítása fontos szerepet játszik egy Formula Student versenyautó teljes akusztikai teljesítményében. Általában a hangtompító beillesztési és átviteli veszteségét használják az 
akusztikai „teljesítménye” becslésére. Számos publikáció érhető el a hangtompítók akusztikus kialakításáról és mérési módszereiről. A piacon három hangtompító típus létezik: visszaverődés elvén alapuló (reaktív), a hangelnyelés elvén alapuló (disszipatív) és hibrid.

Az első típusban a zajcsökkentést a hanghullámok visszaverődése miatt bekövetkező részleges kioltás éri el. Ez alacsony frekvenciatartományban müködik jól. A második típusú jó hangelnyelő anyagokat alkalmaz a zajcsökkentéshez. Az akusztikus energia hővé alakul, majd elnyelődik. Ezt a típust a közepes és magas frekvenciákon alkalmazzák.

A harmadik típus a visszaverődéses és az abszorpciós kombinációja. A hibrid hangtompító széles frekvenciatartományban használható. Ennek a cikknek a célja a Formula Student versenyautó kipufogó rendszer érzékenységének elemzése három kulcsfontosságú tervezési paraméter alapján, azaz a válaszfal (perforált cső) elhelyezkedése, a kamra térfogatának változása és a hangelnyelő anyag beillesztése a reaktív kipufogóba. Mohamad és társai a 2017. évi áttekintésben mutatták be az iparban használt hangtompítókat, és ez az áttekintés az áramlási és hőmérsékleti eloszlást szemlélteti a csővezeték hossza mentén. Leírták a kipufogódob tervezésében alkalmazott, kísérleti, gyakorlati módszereket és bemutatták az átviteli veszteség jellemzésére használt mérőszámokat.

Az 1D akusztikai számítások sokkal gyorsabbak, és még mindig jó közelítést nyújtanak a vizsgált rendszerről. A Mohamad és Amroune 2019-ben számítástechnikai CFD eszközöket alkalmaztak a motor hangtompítójának akusztikus teljesítményére gyakorolt áramlási hatások leírására. Ez bemutatja az átviteli veszteség alakulását különböző frekvenciákon az 1D szimuláció használatával. Mohamad et al 2019-ben az átviteli mátrix módszerét (TMM) mutatta be a kipufogódob átviteli veszteségének számításához. Az algoritmus a kipufogórendszer más részeire is alkalmazható. Egy létező hangtompító ilyen vizsgálatának eredményét összehasonlították a járművön elvégzett. mérés adataival. A hangtompító átviteli veszteségét optimálva egy új hangtompító kialakítást javasoltak. A validálásban nagy szerepet játszott más irodalmi forrásokból vett eredmények. A Mohamad 2019-ben számos új technikát tanulmányozott kipufogórendszerek akusztikus teljesítményének szempontjából irodalomkutatás segítségével. Megmagyarázza mindkét elméleti megközelítés mögött meghúzódó alapelveket, valamint egy zajforrás leírási módszert, amely felhasználható a két módszer összekapcsolására.

\section{A módszer}

A kiinduló hangtompító geometria a jelenlegi versenyautó reaktív hangtompító prototípusa alapján valósult meg a SolidWorks 2017 fejlett tervezőszoftverrel. A modell tartalmazza a bemeneti, kimeneti, a perforált csövet és a kamrát. A perforált csövet a kipufogódob hengeres alakú kamrájának közepére helyeztük. A kipufogódob keresztmetszetét és méreteit az 1. ábra tartalmazza. A hangtompító elnevezése a továbbiakban PPiP lesz.

Számos eljárást készítettünk a modellezés CFD ezközök segítségével történő elvégzésére, valamint az optimális kialakítás elkészítéséhez az AVL BOOST v 2017 felhasználásával történő vizsgálatokhoz. A hangtompító titánötvözetböl készült, és az áramló gáz tulajdonságait közvetlenül mindkét szoftver adatbázisból választottuk ki. Az áramlás akusztikai elemzésénél figyelembe vett peremfeltételek reprezentatívak a kipufogórendszerre több motorfordulatszám esetén is.

Az AVL Boost-ban létrehozott 1D modell az egydimenziós akusztikai megközelítést alkalmazza a dugattyús motor szívó- és kipufogórendszereiben lezajló folyamatok leírására. A probléma egydimenziós megközelítése lehetővé teszi a csövek és csatornák méreteinek (átmérők, hosszúságok, a lekerekítési sugarak) a gázáramra gyakorolt hatásának becslését. A teljes hengert egyetlen térfogatnak tekinti, amelyben a szívás, a sürítés, az égés, a kiterjedés és a kiáramlás folyamata történik. Ez a térfogat, a háromdimenziós megközelítéstől eltérően, nem oszlik altartományokra (kontroll vagy véges térfogatok). 
Az egyenletrendszer (energia, kontinuitás, gázállapot) csak egy olyan térfogatra van felírva, amely az időben változik (háromdimenziós megközelítésben - az egyenletrendszert minden egyes kontrolltérfogatra megoldják).

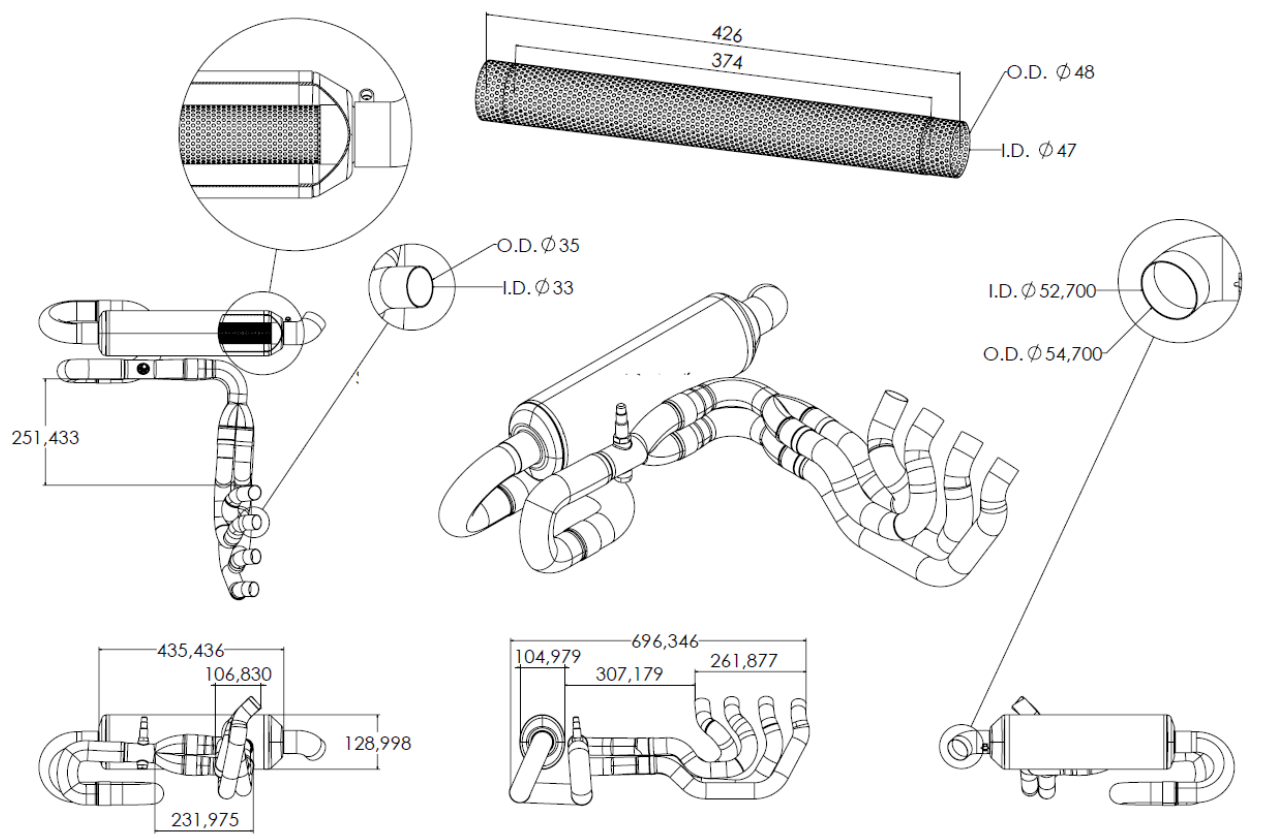

1. ábra. A versenyautó módositott hangtompitójának (PPiP) felépitése

\section{Matematikai analízis}

A matematikai modell a háromdimenziós instacionér tömegáram alapvető egyenletein alapszik: az impulzus (Navier-Stokes), az energia (Fourier-Kirchhoff) és a kontinuitás egyenletein, amelyek Reynoldsféle formájában jelennek meg a Favre - módszer szerinti átlagolás után:

$$
\begin{gathered}
\bar{\rho} \frac{d \overline{W_{i}}}{d t}=\bar{G}_{i}-\frac{\partial \bar{P}}{\partial x_{i}}+\frac{\partial}{\partial x_{j}}\left[\mu\left(\frac{\partial \bar{W}_{i}}{\partial x_{j}}+\frac{\partial \bar{W}_{j}}{\partial x_{i}}-\frac{2}{3} \delta_{i j} \frac{\partial \bar{W}_{k}}{\partial x_{k}}\right)-\bar{\rho}{\overline{W^{\prime}}}_{i} \bar{W}_{j}^{\prime}\right] \\
\bar{\rho} \frac{d \bar{H}}{d t}=\bar{G}_{j} \bar{W}_{j}+\frac{\partial \bar{P}}{\partial t}+\frac{\partial}{\partial x_{i}}\left(\bar{\tau}_{i j} \overline{W_{j}}\right)+\frac{\partial}{\partial x_{j}}\left(\lambda \frac{\partial \bar{T}}{\partial x_{j}}-c_{p} \bar{\rho} \overline{\bar{T}^{\prime} W^{\prime}}{ }_{j}\right) \\
\frac{\partial \bar{\rho}}{\partial t}+\frac{\partial}{\partial x_{j}}\left(\bar{\rho} \bar{W}_{j}\right)=0
\end{gathered}
$$

ahol W a sebesség; p a nyomás, $G_{i}$ a térfogati erők sürüségvektorának vetítése egy derékszögü koordinátarendszer $O_{x i}$ tengelyére, $\mathrm{H}$ a teljes fajlagos energia, $T$ a hőmérséklet, $\mu$ a dinamikus viszkozitás, $c_{p}$ a hőkapacitás állandó nyomáson, $\bar{\tau}_{i j}$ az átlagos Reynolds feszültség, $\lambda$ a hővezető képesség, $\rho$ a sürüség, $\delta_{i j}$ a Kronecker delta; és $\partial / \partial t$ a differenciál operátor.

A transzport egyenletek rendszerét Reynolds formában $(1,2,3$. sz. egyenletek) a $k-\zeta-f$ turbulencia modell zárja le. Ezt a modellt speciálisan fejlesztették ki és ellenőrizték a belsőégésü dugattyús motorok 
áramlási viszonyainak, égési és hőátadási folyamatainak leírására (Tatschl et al, 2005 és Tatschl et al, 2006). A $k-\zeta-f$ modellnek három egyenlete van: a turbulencia $k$ kinetikus energiájára, az energia $\varepsilon$ eloszlási sebességére és a normalizált sebességi $\zeta=\bar{W}^{2} / k$ egyenleteire (Hanjalič et al, 2004).

Ún. „hibrid falfüggvényeket” (Popovać és Hanjalić, 2005) használtunk a gázáram és a határrétegbe történő hőátadás paramétereinek meghatározására. Merker és társai, 2019, Basshuysen és Schäfer, 2007 és Kavtaradze et al, 2009 hangsúlyozzák, hogy ez a matematikai modell alkalmazható a dugattyús motorokban lezajló folyamatok CFD-számításaira.

A motorok kipufogórendszerében található hangtompítók esetében a különbözö hangtompító-felépítések és paraméterek nyilvánvalóan eltérő hatással vannak a zaj csökkentésére. A hangtompítóban lezajló komplex munkafolyamat miatt a kutatók folyamatosan vitatták a hangtompítók belső felépítésének, elméleti számításának és kialakításának módszereit. Az hangelnyelő anyag és a belső cső porozitásának a hangnyomásszintre gyakorolt hatását az alábbi egyenlettel lehet leírni:

Anyag porozitás = 1 - (térfogat sürüség) / (anyag sürüség) [2]

Az anyagjellemzők, pl. sürüség értéket a szoftver adatbázisból származnak.

\section{Eredmények}

\subsection{D szimulációk}

A 2. ábra a hangtompítón belüli áramlási sebesség eloszlását mutatja. Mint látható, a legnagyobb áramlási sebesség a perforált csövet tartalmazó hangtompító kimeneténél található könyökben volt, a legnagyobb nyomás pedig a bementnél volt, ahogy azt a 3. ábra mutatja.
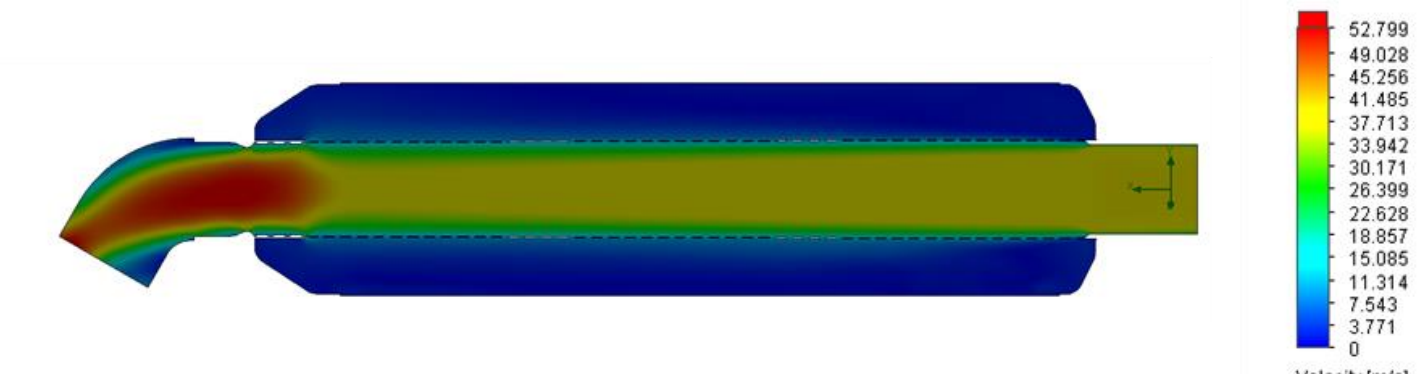

Cut Plot 1(hor.): contours

2. ábra. A sebességeloszlás a bemenettöl (jobb oldal) a kimenetig (bal oldal) a PPiP hangtompitóban

A perforált csöves hangtompítóba bejutó gáz nagy része közvetlenül a perforált csőből jut a hangtompító belső térfogatába. A perforált cső furatainak átmérője $3 \mathrm{~mm}$ volt. A nagy áramlási ellenállás miatt a gáz energiája jelentősen csökken, amikor a furatokon keresztüláramlik.

Háromdimenziós CFD számítások alapján meghatároztuk a kipufogó nyomásesésének értékét, figyelembe véve a belső perforált cső jelenlétét is. A háromdimenziós modellek lehetővé tették az anyagporozitás értékének tisztázását is. Ezeket az értékeket tovább használtuk az 1D kipufogórendszer-modell kalibrálásához az AVL Boost rendszerben. 

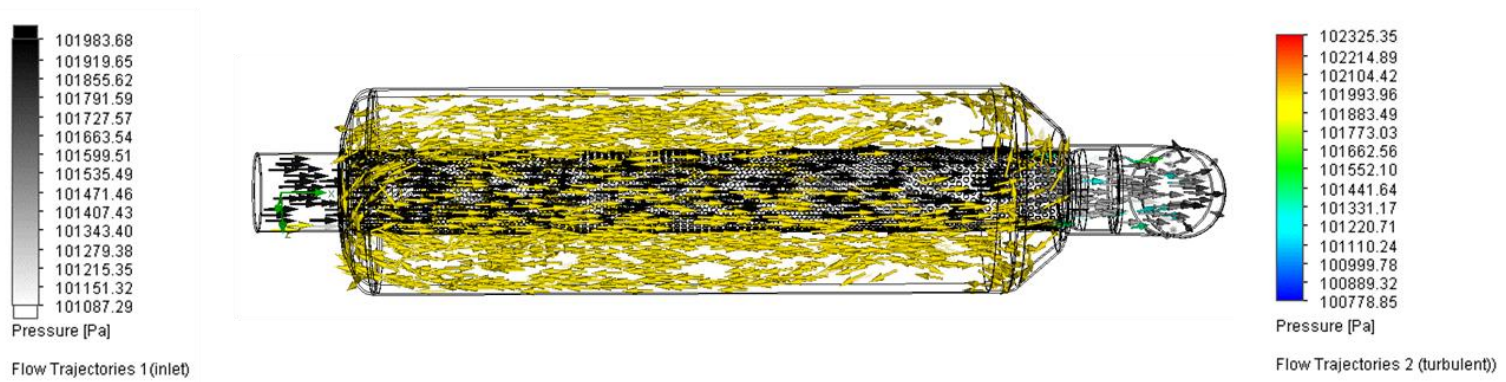

3. ábra. Nyomáskontúr (áramlási irányvonalak) a perforált csőben és a hangtompitó térfogati részében (bal oldal: bemenet, jobb oldal kimenet)

\subsection{A motor teljesítményének változása}

A további vizsgálatokhoz a hangtompító következő paramétereit használtuk, ill. variáltuk: átmérő $\left(D_{m_{-} i n}\right)$, a perforált belső cső furatának átméröje $\left(D_{m_{-} \text {hole }}\right)$, a hangtompító héj külső átmérője $\left(D_{m_{-} \text {out }}\right)$, valamint a hosszát $\left(\mathrm{L}_{\mathrm{m}}\right)$. A paraméterek változtatásával és az AVL BOOST szoftver segítségével figyeltük, hogy a motor teljesítménye mennyiben változik. Különböző típusú kipufogó hangtompító alkalmazása az aktuális Formula Student motornál csak kevéssé befolyásolja a teljesítményt, mivel nincs katalizátor, vagy közbenső hütő, amely magas ellennyomást hozna létre.

\subsection{A hangtompító típusának, geometriájának és felépítésének hatása a zajra}

Amint azt a 4. ábra mutatja, a módosított (PPiP) hangtompító lehetővé teszi a zajszint csökkentését, de $n>30001 /$ min érték fölött a zajszint továbbra is magasabb, mint a csak kamrás hangtompító esetén. Ez a cikk a hangtompító össz-hangnyomásszintjének optimalizálására irányult, ahelyett, hogy azt minden egyes frekvencián vizsgálná. A módosított hangtompítóban olyan hatások érvényesülhetnek, amelyek csak bizonyos frekvencián fejtik ki hatásukat, viszont megnövelik az össz-hangnyomásszintet.

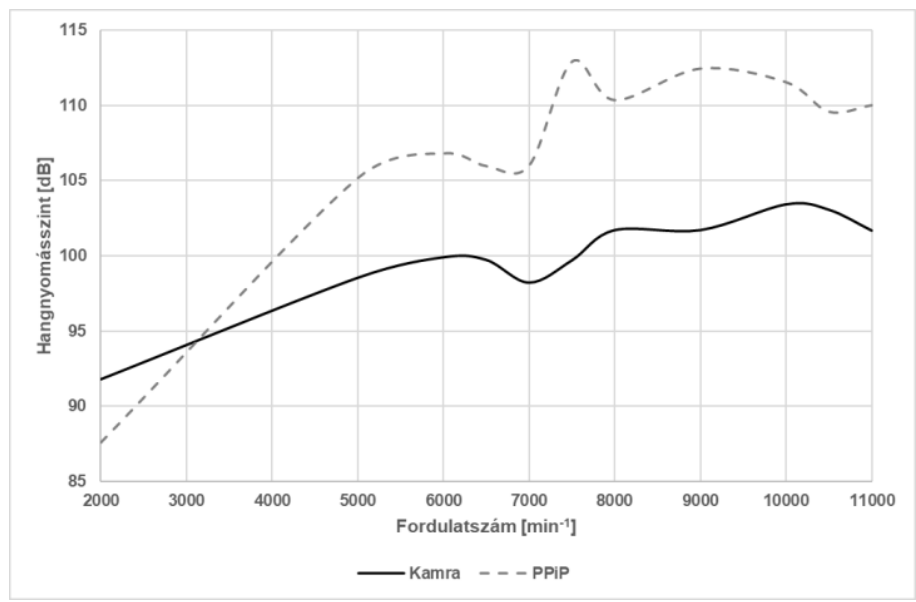

4. ábra. A Honda CBR 600RR (PC 37) versenyautómotor hangnyomásszintjének összehasonlitása térfogat és PPiP hangtompitók esetén 
A hangtompító geometriai paramétereinek a zajcsökkentésre gyakorolt hatását is tanulmányoztuk. Az 5. ábra a motor zajszintjének összehasonlítását mutatja $1 \mathrm{~m}$ távolságra a hangtompító kimeneti nyílásától, alap és módosított hangtompító alkalmazása esetén. Az kipufogógáz áramlási zaj terjedésének szimulálása és az azt befolyásoló tényezők tárgyalása, ennek a kombinációs elméletnek a hatékonyságát tükrözi gyakorlati körülmények között, mivel a hangtompító motor általi gerjesztési forrása inkább a nyomásváltozás, szemben a rezgési sebességgel, amikor a hangtompítót az autó motorjához csatlakoztatjuk.

A motor müködési paramétereinek, beleértve a zajszintet, a kimeneti cső hosszától való jelentős függését a cső nyitott végéből hátrafele terjedő hullámok határozzák meg. Ennek eredményeként a motor teljesítményének fenntartása mellett a legalacsonyabb zajszintet érjük el, ha $D_{m_{-} \text {out }}=126 \mathrm{~mm}$ és $\mathrm{L}_{\mathrm{m}}=436 \mathrm{~mm}$.

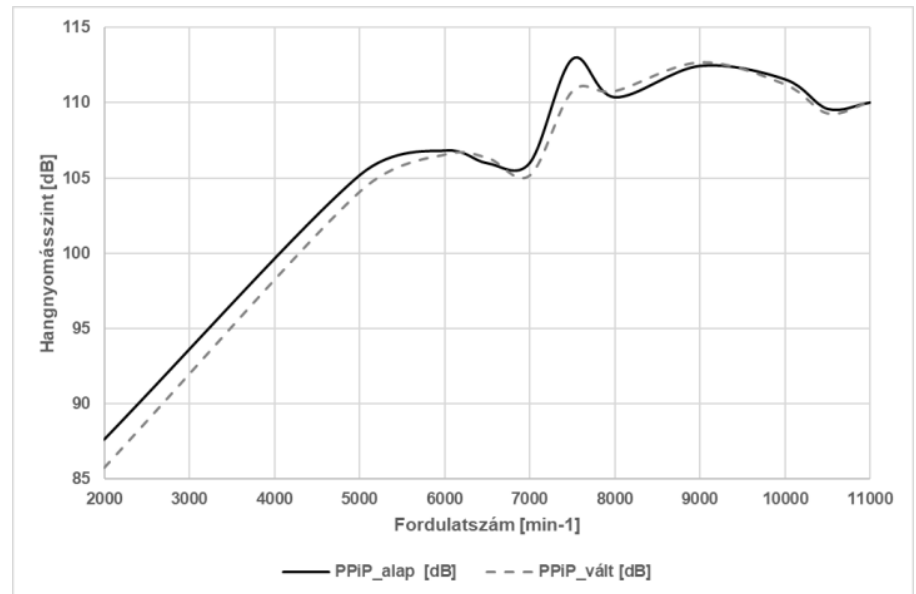

5. ábra. A Honda motor akusztikus teljesitménye kiinduló geometriájú PPiP hangtompító $\left(D_{m \_n o l e}=\right.$ $\left.3 \mathrm{~mm}, D_{m_{-} i n}=47 \mathrm{~mm}, D_{m_{-} o u t}=116 \mathrm{~mm}, L_{m}=426 \mathrm{~mm}\right)$ és módositott geometriájú PPiP hangtompitó

$$
\text { ( } \left.D_{m_{-} \text {hole }}=3 \mathrm{~mm}, D_{m_{-} \text {in }}=47 \mathrm{~mm}, D_{m_{-} \text {out }}=126 \mathrm{~mm}, L_{m}=436 \mathrm{~mm}\right) \text { esetén }
$$

Vizsgáltuk továbbá hangelnyelö anyag alkalmazásának hatékonyságát is a hangtompító zajcsökkentésének szempontjából. Hangelnyelő anyag peremfeltételeit alkalmaztuk a szimulációban tényleges fizikai vastagság nélkül. Ilyen módon hangelnyelő anyagot „helyeztünk” a külső héj belső oldalára (PPiP w AM in OP), a perforált cső külső oldalára (PPiP w AM in IP), valamint számításokat végeztünk az előző két eset kombinációjára is (PPiP w AM in IP \& OP).

A 6. ábra mutatja, hogy a hangelnyelő anyag alkalmazása lehetővé teszi a hangnyomásszint 15-20\% kal történő csökkentését a teljes motorfordulatszám tartományban. A motor teljesítményét számítva azonban észrevehetjük, hogy növekszik a kimeneti áramlási ellenállás, ezáltal csökken a motor teljesítménye.

Ezen kívül a motor müködése közben a hangelnyelő anyag eltömődhet a kipufogógázokban lévő koromrészecskékkel, ami további növeli az áramlási ellenállást és a motor müködési körülményeinek további változását, leginkább romlását okozza.

A fö hangtompítónak nemcsak könnyebb tömege volt, hanem ahhoz is szüksége volt, hogy biztosítsa a minimális hangnyomásszintet a kimenetnél, ami többcélú optimalizálási probléma. Az összes optimalizálási folyamatot a kereskedelmi forgalomban elérhető szoftverrel hajtottuk végre.

A hangelnyelö anyag használata lényegesen nagyobb csökkenést eredményez a motor zajszintjében hasonló méretủ hangtompítók alkalmazása esetén. A hangelnyelő anyag paraméterei: porozitás $\sigma=0,9$, 
áramlási ellenállás $R=10000 \mathrm{Ns} / \mathrm{m}^{4}$. Az anyag porozitása a levegőnek az anyagon belüli hányadát képviseli (0-1). Esetünkben a 0.9 anyagporozitás azt határozza meg, hogy a térfogat $10 \%$-a anyag, és $90 \%$ - a levegővel töltött.

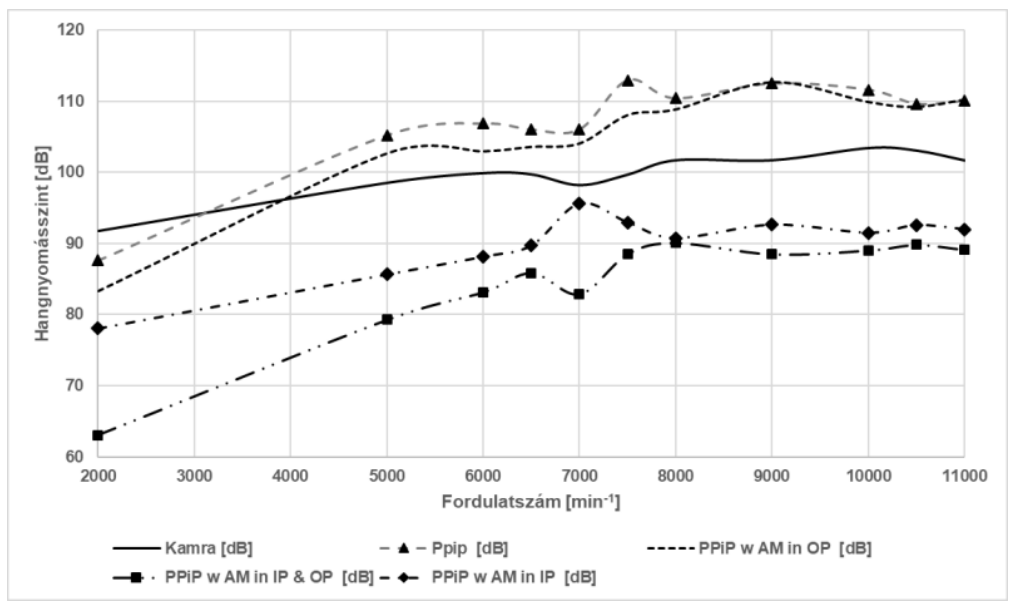

6. ábra. A Formula Student versenyautó motor hangnyomás szintje különféle kialakitású hangtompitóval

\section{5. Összefoglalás}

A vizsgált motor akusztikai problémáját ezek alapján hangelnyelö anyag felhasználásával oldhatjuk meg. Ez a zajszint további csökkentésének lehetséges lépése. Ezek után a hangtompító megfelelhet a kipufogó zaj a versenyszabályzatban foglalt elöírásainak. Az 1D és 3D szimulációk használata a kipufogórendszerben jelentősen csökkentheti a kipufogórendszerek optimális méretének kiválasztásához szükséges időt és költségeket. Esetünkben az eredmények nagyban hozzájárulhatnak ahhoz, hogy versanyautó tervezői, használói sikeresen kiválasszák a kipufogódob megfelelő felépítését méretét és abszorpciós anyagát úgy, hogy a versenyautó, nemcsak akusztikai szempontból, versenyképes legyen.

\section{Köszönetnyilvánítás}

A cikkben ismertetett kutató munka az EFOP-3.6.1-16-2016-00011 jelü „Fiatalodó és Megújuló Egyetem - Innovatív Tudásváros - a Miskolci Egyetem intelligens szakosodást szolgáló intézményi fejlesztése" projekt részeként - a Széchenyi 2020 keretében - az Európai Unió támogatásával, az Európai Szociális Alap társfinanszírozásával valósul meg.

\section{Irodalom}

[1] Mohamad, B., Szepesi, G., Bolló, B.: Review Article: Modelling and analysis of a gasoline engine exhaust gas systems, 2017, 5th International Scientific Conference on Advances in Mechanical Engineering, University of Debrecen-Hungary, pp. 345-357.

[2] Mohamad, B., Amroune, S.: The analysis and effects of flow acoustic in a commercial automotive exhaust system, 2019, Advances and Trends in Engineering Sciences and Technologies III, Proceedings of the 3rd International Conference on Engineering Sciences and Technologies (ESaT 2018), September 12-14, 2018, High Tatras Mountains, Tatranské Matliare, Slovak Republic, pp. 197-202. 
[3] Mohamad, B., Jalics, K., Kermani, M.: Exhaust system muffler volume optimization of light commercial passenger car using transfer matrix method, International Journal of Engineering and Management Sciences (IJEMS), 4, (2019) pp. 132-139.

https://doi.org/10.21791/IJEMS.2019.1.16.

[4] Mohamad, B.: A review of flow acoustic effects on a commercial automotive exhaust system, Mobility and Vehicle Mechanics, 45, (2), (2019) pp. 1-4.

https://doi.org/10.24874/mvm.2019.45.02.01

[5] Cherng, J., Wu, W., Ding, P., Hebbes, M., Zhang, H.: Design optimization of vehicle muffler transmission loss using hybrid method, SAE technical paper 2015-01-2306, 2015. https://doi.org/10.4271/2015-01-2306

[6] Gardner, B., Mejdi, A., Musser, C., Chaigne, S. Macarios, T.: Coupled CFD and vibro-acoustic modeling of complex-shaped mufflers accounting for non-uniform mean flow effects, SAE technical paper 2015-01-2313, 2015. https://doi.org/10.4271/2015-01-2313

[7] Brohmer, A., Mehring, J., Schneider, J., Basara, B., Tatschl, R., Hanjalic, K., Popovac, M.: Progress in the 3D-CFD calculation of the gas and water side heat transfer in engines, 2005, in Verfahren 10 Tagung der Arbeitsprozess des Verbrennungsmotors (Proc. 10th Meeting on the Working Process of the Internal Combustion Engine), Graz, Austria

[8] Hanjalić, K., Popovać, M., Hadziabdić, M.: A Robust Near-Wall Elliptic-Relaxation Eddy-Viscosity Turbulence Model for CFD, Int. J. Heat Fluid Flow (2004), 25. pp. 897-901. https://doi.org/10.1016/j.ijheatfluidflow.2004.07.005

[9] Tatschl, R., Basara, B., Schneider J., Hanjalic, K., Popovac, M., Brohmer, A., Mehring, J.: Advanced Turbulent Heat Transfer Modeling for IC-Engine Applications Using AVL FIRE, 2006, Proceedings of International Multidimensional Engine Modeling User's Group Meeting. Detroit, USA.

[10] Popovać, M., Hanjalić, K.: Compound Wall Treatment for RANS Computation of Complex Turbulent Flow, 2005, Proc. 3rd M.I.T. Conference, Boston, USA

[11] Merker, G., Schwarz, Ch., Teichmann, R.: Grundlagen Verbrennungsmotoren: Funktionsweise, Simulation, Messtechnik (Fundamentals of Internal Combustion Engines: Mode of Operation, Simulation, Measurement Technology), 2019, 9th ed.; Springer: Wiesbaden, 1117 p.

[12] Basshuysen, R., Schäfer, F.: (Hrsg.) Handbuch Verbrennungsmotor, 4. Auflage, Vieweg und Sohn Verlag, Wiesbaden, 2007., 1032 p.

[13] Kavtaradze, R. Z., Onishchenko, D. O., Zelentsov, A. A., Sergeev, S. S.: The influence of rotational charge motion intensity on nitric oxide formation in gas-engine cylinder, Int. J. Heat Mass Tran. 2009, 52, pp. 4308-4316. https://doi.org/10.1016/j.ijheatmasstransfer.2009.03.060 